\title{
IMPACT OF GRANZYME B GENE EXPRESSION ON INFLAMMATION AND INSULIN RESISTANCE IN ATHEROSCLEROSIS
}

\author{
Hala O. El-Mesallamy ${ }^{1}$, Nadia M. Hamdy ${ }^{1}$, Yassin A. Ibrahim², Adel k. Al-Etriby ${ }^{3}$ and \\ Eman F. Sanad ${ }^{\text {* }}$ \\ ${ }^{1}$ Biochemistry Department, Faculty of Pharmacy, Ain Shams University, Abassia, Cairo \\ 11566, Egypt. \\ ${ }^{2}$ Cardiothoracic Surgery Department, Kobry El-Kobba Military Hospitals, Abassia, Cairo, \\ Egypt. \\ ${ }^{3}$ Cardiology Department, Faculty of Medicine, Ain Shams University, Abassia, Cairo \\ 11566, Egypt.
}

\section{ABSTRACT:}

Background/Aim: Atherosclerosis is an inflammatory disease in which many immune cells are accumulated. Cytotoxic $\mathrm{T}$ lymphocytes, the dominant immune cells in advanced atherosclerotic lesions, exert their activity via proapoptotic protease granzyme B (GZB). However, increased GZB was detected in atherosclerotic lesions, its exact role and contribution toward atherosclerosis-related key regulatory processes yet unclear.

Method: GZB mRNA expression was quantified in peripheral blood of 15 apparently healthy controls and 58 atherosclerotic patients divided into 23 non-diabetic and 35 diabetic patients by Taqman RT-PCR. Serum high sensitivity C-reactive protein and insulin levels were estimated by ELISA.

Results: There is a significant 3-fold increase in GZB mRNA in atherosclerotic patients compared to control $(P<0.001)$. Moreover, GZB mRNA levels were positively correlated with cardiovascular risk ratios, markers of inflammation and insulin resistance. Multiple regression analysis revealed that DM and current smoking were significant predictors for GZB gene expression.

Conclusions: GZB might have a role in inflammation and insulin resistance processes associated with atherosclerosis development and progression.

Key words:

Granzyme B, inflammation, insulin resistance, atherosclerosis

\section{INTRODUCTION:}

Atherosclerosis is a chronic inflammatory disease responsible for the majority of cardiovascular disease (CVD), one of major causes of death world-wide. Despite declines in CVD mortality over the past several decades, diabetes mellitus (DM) remains a key risk factor for CVD with a 2- to 4-fold higher risk of CVD, as well as an increased risk of mortality by up to 3-fold than those without DM (Gregg, et al., 2007; Preis et al., 2009). Accumulating evidence showed that increased risk for CVD in type $2 \mathrm{DM}$ is likely due to insulin resistance and underlying mechanisms of dyslipidemia, systemic inflammation and oxidative stress (Gregg, et al., 2007; Grundy, et al., 1999). 
Atherosclerosis was formerly identified as bland lipid-driven disease in which smooth muscle cells (SMCs) and endothelial cells are central effectors. However, substantial advances in basic and experimental investigations recognized many immune cells and mediators in atheroma, implicating inflammation as key regulatory process in all stages of atherosclerosis (Libby, et al., 2009; Mallat, et al., 2009). Activated immune cells appear to play a major role in fibrous cap degradation and subsequent plaque rupture (Ovchinnikova, et al., 2009). Inflammatory response is indicated by circulating levels of biomarkers such as high sensitivity C-reactive protein (hsCRP) (Schaub, et al., 2012). It is worse mentioned that inflammatory response caused by immune cells such as macrophages and T-cells ultimately leads to insulin resistance, a hallmark of atherosclerosis and DM (Shoelson, et al., 2006).

Cytotoxic $\mathrm{T}$ lymphocytes (CTLs) account for about $50 \%$ of leucocytes infiltrate in advanced human atherosclerotic lesions, highlighting their critical role in atherogenesis (Mallat, et al., 2009; Kyaw, et al., 2013). CTLs exert their cytotoxic activity mainly via structurally related superfamily of serine proteases known as granzymes (Ewen, et al., 2012). Granzyme B (GZB) is the most studied and best characterized member of granzymes family. Recent reports have shown that GZB is also expressed by various immune and non-immune cells such as neutrophils, mast cells, SMCs and macrophage (Pardo, et al., 2007; Kim, et al., 2007; Choy, et al., 2003). Both CTLs and macrophages are key inflammatory cells within atherosclerotic lesions (Kyaw, et al., 2013; Choy, et al., 2003).

Until recently, intracellular role of GZB, specifically in the context of apoptosis via caspase-dependent and independent pathways was extensively studied. However, several lines of evidence now suggest a possible critical extracellular role of GZB in many chronic inflammatory conditions (Boivin, et al., 2009). GZB is released from activated CTLs into the extracellular spaces during target cell engagement, or even in absence of target cell engagement (Prakash, et al., 2008). Indeed, soluble forms of GZB were reported in plasma of normal individuals and increased in many inflammatory diseases such as unstable angina, acute myocardial infarction (AMI) (Kondo, et al., 2009) and DM (Ikemoto, et al., 2009). However, increased GZB expression from leucocytes infiltrating atherosclerotic lesions together with SMCs was reported (Kim, et al., 2007), its expression in circulating leucocytes and its association with inflammatory response in atherosclerosis complicated with type $2 \mathrm{DM}$ are not clearly investigated.

Hence, the current study was set out to assess the expression pattern of human GZB gene in peripheral blood of atherosclerotic coronary artery disease (CAD) patients. Furthermore, the relation of GZB to inflammatory activity (hsCRP) and insulin resistance as well as other metabolic (lipids), anthropometric and risk factors in atherosclerosis and type 2 DM-associated cardiovascular complications were being evaluated.

\section{SUBJECTS AND METHODS:}

\subsection{Subjects:}

A total of 73 males were enrolled in this study as follows; 58 atherosclerotic patients undergoing coronary artery bypass graft, being compared to 15 age-matched apparently healthy volunteers as the control group. Patients were subdivided into CAD/non-diabetic group; 23 patients and $\mathrm{CAD} /$ diabetic group; 35 patients. CAD patients were recruited from Cardiothroacic Surgery Department of Kobry El-Kobba Military Hospitals, Cairo, Egypt. A detailed family, 
medical history and drug treatment were collected for all subjects. The general characteristics of the studied subjects are summarized in Table 1. Anthropometric parameters measured included body mass index (BMI). BMI was calculated as an index of the weight in kilograms divided by the square of the height in meters.

Table (1): Demographic data and biochemical parameters in control and CAD subgroups:

\begin{tabular}{|c|c|c|c|}
\hline Parameters/Groups (n) & Control (15) & CAD/non-diabetic (23) & CAD/diabetic (35) \\
\hline Age (years) & $52.53 \pm 0.83$ & $53.17 \pm 1.26$ & $54.94 \pm 0.78$ \\
\hline Body mass index $\left(\mathrm{kg} / \mathrm{m}^{2}\right)$ & $26.42 \pm 0.29$ & $25.58 \pm 0.36$ & $26.69 \pm 0.35$ \\
\hline Current smoking, $\mathbf{n}(\%)^{*}$ & $1(6.7 \%)$ & $10(43.5)^{\mathrm{a}}$ & $17(48.6)^{\mathrm{a}}$ \\
\hline Hypertension, $\mathbf{n}(\%) *$ & $0(0 \%)$ & $14(60.9)^{\mathrm{a}}$ & $26(74 . .3)^{\mathrm{a}}$ \\
\hline Triglycerides (mg\%) & $89.27 \pm 6.95$ & $129.65 \pm 7.50^{\mathrm{a}}$ & $156.863 \pm 10.06^{\mathrm{a}, \mathrm{b}}$ \\
\hline Total cholesterol (mg\%) & $153.00 \pm 3.86$ & $175.78 \pm 4.51^{\mathrm{a}}$ & $191.66 \pm 4.52^{\mathrm{a}, \mathrm{b}}$ \\
\hline HDL-C (mg\%) & $50.93 \pm 2.08$ & $37.52 \pm 1.78^{\mathrm{a}}$ & $36.74 \pm 1.22^{\mathrm{a}}$ \\
\hline LDL-C (mg\%) & $84.21 \pm 2.98$ & $112.33 \pm 3.63^{\mathrm{a}}$ & $123.54 \pm 3.87^{\mathrm{a}, \mathrm{b}}$ \\
\hline TC/HDL-C & $3.06 \pm 0.13$ & $4.89 \pm 0.23^{\mathrm{a}}$ & $5.42 \pm 0.23^{\mathrm{a}}$ \\
\hline LDL-C/HDL-C & $1.70 \pm 0.10$ & $3.17 \pm 0.20^{\mathrm{a}}$ & $3.52 \pm 0.18^{\mathrm{a}}$ \\
\hline FBG (mg\%) & $91.93 \pm 1.44$ & $101.30 \pm 2.07$ & $176.71 \pm 7.30^{\mathrm{a}, \mathrm{b}}$ \\
\hline $\mathrm{HbA}_{1 \mathrm{c}}(\%)$ & $5.39 \pm 0.07$ & $5.78 \pm 0.05$ & $8.12 \pm 0.24^{\mathrm{a}, \mathrm{b}}$ \\
\hline Fasting insulin ${ }^{\mathbb{I}}$ & $4.05 \pm 0.44$ & $10.95 \pm 1.79^{\mathrm{a}}$ & $10.15 \pm 1.42^{\mathrm{a}}$ \\
\hline HOMA-IR ${ }^{\mathrm{II}}$ & $0.93 \pm 0.11$ & $2.77 \pm 0.48^{\mathrm{a}}$ & $4.25 \pm 0.61^{\mathrm{a}, \mathrm{b}}$ \\
\hline QUICKI & $0.40 \pm 0.01$ & $0.35 \pm 0.01^{\mathrm{a}}$ & $0.32 \pm 0.01^{\mathrm{a}, \mathrm{b}}$ \\
\hline WBCs count $\left(10^{3}\right.$ cells $\left./ \mathrm{cm}^{3}\right)$ & $5.39 \pm 0.25$ & $7.52 \pm 0.51^{\mathrm{a}}$ & $6.89 \pm 0.31^{\mathrm{a}}$ \\
\hline $\begin{array}{l}\text { Neutrophils count (\% of } \\
\text { WBCs) }\end{array}$ & $51.00 \pm 1.52$ & $62.83 \pm 1.81^{\mathrm{a}}$ & $59.09 \pm 1.55^{\mathrm{a}}$ \\
\hline $\operatorname{hsCRP}(\mathbf{m g} / \mathrm{L})^{\text {II }}$ & $0.97 \pm 0.25$ & $4.70 \pm 0.81^{\mathrm{a}}$ & $12.54 \pm 2.12^{\mathrm{a}, \mathrm{b}}$ \\
\hline $\begin{array}{l}\text { GZB mRNA (fold } \\
\text { expression) }\end{array}$ & $1.00 \pm 0.01$ & $2.68 \pm 0.33^{\mathrm{a}}$ & $3.67 \pm 0.32^{\mathrm{a}, \mathrm{b}}$ \\
\hline
\end{tabular}

Data are expressed as mean \pm SEM

a: significantly different from control at $p \leq 0.05$

b: significantly different from CVD/non-diabetic at $p \leq 0.05$

*: parameter analyzed by chi-square test

II: parameter analyzed by Kruskal-Wallis test

CAD, coronary artery disease; TC, total cholesterol ; HDL-C, high density lipoprotein cholesterol; LDL-C; low density lipoprotein cholesterol; FBG, fasting blood glucose; GHbA1c, glycosylated hemoglobin; QUICKI, Quantitative insulin sensitivity check index; HOMA-IR, homeostasis model assessment of insulin resistance; WBCs, white blood cells; hsCRP, high sensitivity C-reactive protein; GZB, granzyme B.

Subjects with history of type 1 DM, inflammatory diseases, autoimmune disorders, malignancy, hematological diseases, renal diseases or chronic liver disease were excluded from the study. Also, obese subjects with BMI $\geq 30 \mathrm{~kg} / \mathrm{m}^{2}$ were excluded. The study protocol was approved by ethical committees of Kobry El-Kobba Military Hospitals and Faculty of 
Pharmacy, Ain Shams University, Cairo, Egypt. The study was carried out in accordance with the regulations and recommendations of the Declaration of Helsinki and a written informed consent was obtained from all participants.

\subsection{Specimens:}

Peripheral blood samples $(10 \mathrm{~mL})$ were collected from patients before the surgery and from controls after an overnight fasting. Blood samples were divided into 3 aliquots; the first aliquot of blood was collected on vacutainer tubes containing sodium fluoride for plasma preparation used for the assay of FBG. The second aliquot was collected on vacutainer tubes containing $\mathrm{Na}_{2}$-EDTA for whole blood preparation used for the assay of glycosylated hemoglobin $\left(\mathrm{HbA}_{1 \mathrm{c}} \%\right)$, complete blood count and RNA isolation within 1-3 hours after collection. The third aliquot was collected on plain vacutainer tubes for serum preparation used for the assay of lipids profile. The remaining serum and plasma were divided into several aliquots and stored at $-60^{\circ} \mathrm{C}$ for subsequent assay.

\subsection{Biochemical Analysis:}

Serum biochemical parameters including: triglycerides, total cholesterol (TC), high density lipoprotein cholesterol (HDL-C), low density lipoprotein cholesterol (LDL-C) and plasma FBG were determined using Roche/MODULAR automated analyzer (Roche Diagnostics). $\mathrm{HbA}_{1 \mathrm{c}} \%$ was measured in whole blood with ion-exchange high-performance liquid chromatography using the Bio-Rad VARIANT II system (Bio-Rad Laboratories, Hercules, CA). Complete blood count was determined by Sysmex XT 2000i automated hematology analyzer (Sysmex Corporation, Japan).

Fasting serum insulin levels were determined by enzyme linked immunosorbent assay (ELISA) kit supplied by Immunospec Inc, USA. The homeostasis model assessment of insulin resistance (HOMA-IR) was calculated from fasting insulin and FBG by the following equation: HOMA-IR= fasting insulin $(\mu \mathrm{U} / \mathrm{mL}) \times$ FBG $(\mathrm{mg} / \mathrm{dL}) / 405$ (Matthews, et al., 1985). The quantitative insulin sensitivity check index (QUICKI) was calculated by the following equation: QUICKI= $1 /[\log ($ Fasting insulin $)+\log (\mathrm{FBG})]$ (Katz, et al., 2000). Serum hsCRP levels were estimated by ELISA technique using commercially available ELISA kit supplied by Monobind Inc, USA. All ELISA procedures were done by Hyprep automated ELISA system (Hyperion Inc, Miami, FL) according to the manufacturer's instructions.

\subsection{RNA Isolation and cDNA synthesis:}

Total RNA was extracted from whole blood by QIAamp RNA Blood Mini kit (Qiagen, Germany). NanoDrop 2000 (Thermo Scientific, USA) was used to determine RNA concentration and purity. Total RNA (500 ng) was reversely transcribed to cDNA with High Capacity RNA-to-cDNA Master Mix (Applied Biosystems, USA). cDNA (final volume of 20 $\mu \mathrm{L}$ ) was stored at $-20^{\circ} \mathrm{C}$ for subsequent quantification of human GZB gene.

\subsection{Real-Time Quantitative PCR:}

Real-time PCR analysis was performed on Applied Biosystems 7500 Real-Time PCR instrument using Taqman® Universal Master Mix II (Applied Biosystems) containing AmpErase uracil-N-glycosylase (UNG). Primers and probe Taqman ${ }^{\circledR}$ gene expression assays for human GZB and glyceraldehyde-3-phosphate dehydrogenase (GAPDH; housekeeping gene) were supplied by Applied Biosystems (Hs0015543355_m1 and Hs02758991_g1, respectively). Taqman real-time PCR was performed using $50 \mathrm{ng}$ cDNA template, $1 \mu \mathrm{L}$ Taqman ${ }^{\circledR}$ gene 
expression assay and $10 \mu \mathrm{L}$ Taqman ${ }^{\circledR}$ universal master mix in final volume of $20 \mu \mathrm{L}$. The reaction PCR protocol used involved heating for $2 \mathrm{~min}$ at $50^{\circ} \mathrm{C}$ for $\mathrm{UNG}$ activation to remove any uracil incorporated into the cDNA then heating for $10 \mathrm{~min}$ at $95^{\circ} \mathrm{C}$ for polymerase activation, followed by 40 cycles of amplification $\left(15 \mathrm{~s}\right.$ at $95^{\circ} \mathrm{C}$ and $1 \mathrm{~min}$ at $\left.60^{\circ} \mathrm{C}\right)$. Relative quantification of target gene in samples was expressed as fold-induction of the target gene compared to the reference gene according to the formula $2^{-\Delta \Delta \mathrm{Ct}}$ method, where $\Delta \Delta \mathrm{Ct}=(\mathrm{Ct}$ target gene - Ct GAPDH $)_{\text {sample }}-(\mathrm{Ct} \text { target gene }-\mathrm{Ct} \text { GAPDH })_{\text {control }}$ and $\mathrm{Ct}$ is the threshold cycle. A negative control using nuclease-free water instead of cDNA template was included in each experiment.

\subsection{Statistical Analysis:}

Data were expressed as mean \pm SEM. Comparison between groups was done using oneway ANOVA for parametric variables and Kruskal Wallis test for nonparametric data. Correlations between markers were analyzed with Ranked Spearman test. Finally, multiple stepwise linear regression analysis was performed to examine factors significantly associated with GZB gene as a dependent variable. Statistical significance was accepted when the $p$ values were $\leq 0.05$. All statistical analysis was performed by IBM statistical package for social sciences (SPSS) statistics version 16.0.

\section{RESULTS:}

\subsection{Group comparisons of the studied population:}

General and laboratories parameters of the studied groups are summarized in Table (1). There was no significant difference between groups in age and BMI. Regarding lipids profile, both CAD subgroups showed significant increase in triglycerides, TC, LDL-C and cardiovascular risk ratios (TC/HDL-C and LDL-C/HDL-C) as well as significant decrease in HDL-C levels in comparison to control group $(P \leq 0.01)$. Moreover, triglycerides, TC and LDL-C were significantly elevated in $\mathrm{CAD} /$ diabetic patients compared to $\mathrm{CAD} /$ non-diabetic patients $(P \leq 0.05)$.

Concerning $\mathrm{FBG}$ and $\mathrm{HbA}_{1 \mathrm{c}} \%$, only $\mathrm{CAD} /$ diabetic but not $\mathrm{CAD} /$ non-diabetic group showed significant elevation compared to the control group $(P \leq 0.0001)$. While both CAD subgroups showed significant elevation in fasting insulin levels and insulin resistance index; HOMA-IR as well as significant reduction in QUICKI index as compared to the control group $(P<0.01)$. This significance remained between both CAD subgroups in HOMA-IR and QUICKI index $(P<0.05)$. As revealed in Table (1) and Figure (1), levels of serum hsCRP and GZB mRNA showed significant elevation in both CAD subgroups as compared to control group $(P<0.0001)$. Additionally, serum hsCRP and GZB mRNA levels tended to be significantly higher in $\mathrm{CAD} /$ diabetic than $\mathrm{CAD} /$ non-diabetic $(P<0.01$ and 0.05 , respectively). 

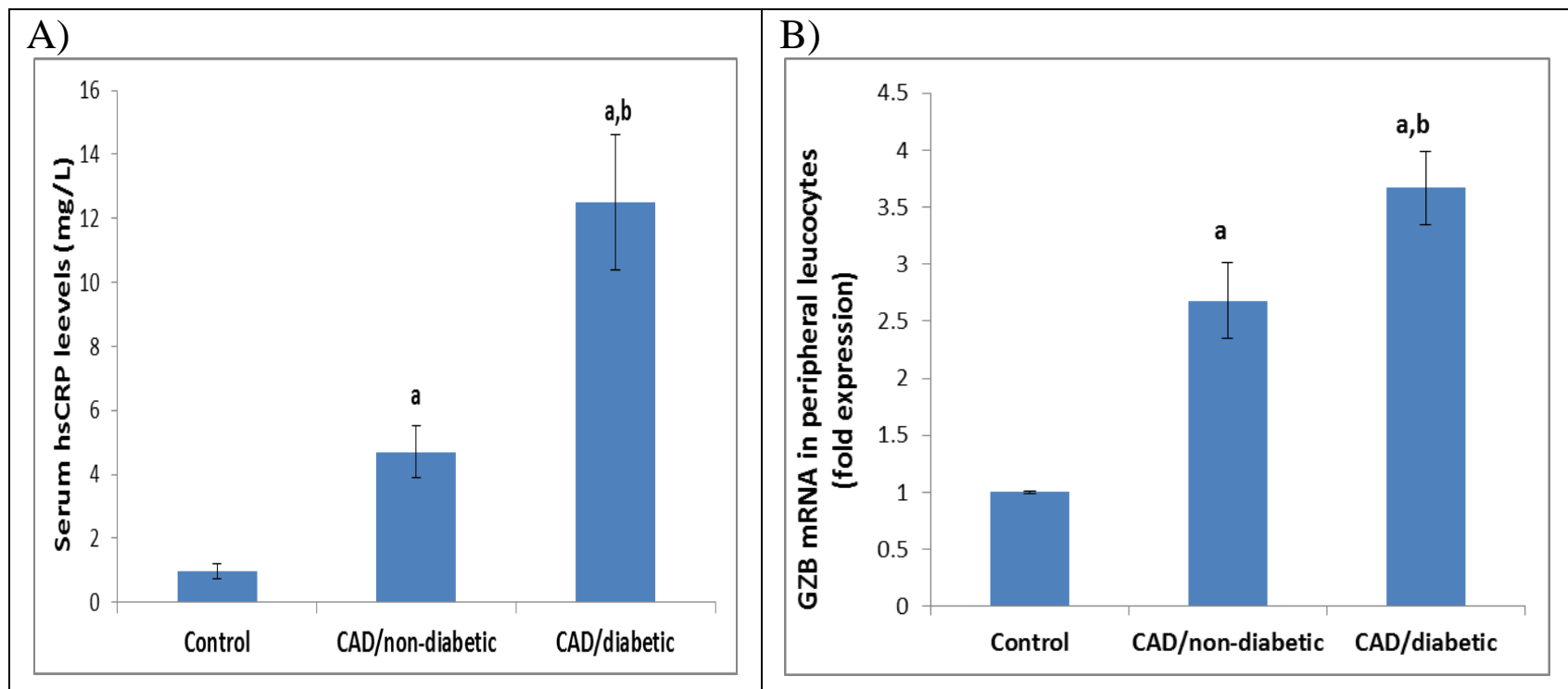

Figure (1): (A) Serum hsCRP levels (B) GZB mRNA expression levels in peripheral leucocytes. Data are expressed as mean \pm SEM and analyzed by Kruskal Wallis test. a; significantly different from control at $P \leq 0.001$, b; significantly different from CAD/non-diabetic at $P \leq 0.05$.

\subsection{Correlation between anthropometric and metabolic parameters and GZB mRNA:}

As shown in Table (2) and Figure (2), investigation of bivariate correlation between GZB mRNA and anthropometric and metabolic parameters revealed that GZB mRNA was positively correlated with triglycerides, TC and LDL-C $(r=0.342,0.426$ and 0.515 at $P<0.01$, respectively) as well as cardiovascular risk ratios (TC/HDL-C and LDL-C/HDL-C) $(r=0.475$ and 0.463 at $P<0.001$, respectively) Also, GZB mRNA was positively correlated with FBG, $\mathrm{HbA}_{1 \mathrm{c}} \%$, and HOMA-IR $(r=0.564,0.496$ and 0.447 at $P<0.001$, respectively). Regarding markers of inflammation, GZB mRNA showed significant positive association with hsCRP and neutrophils count ( $r=0.479$ and 0.305 at $P<0.01$, respectively) as well as white blood cells (WBCs) count $(r=0.265$ at $P<0.05)$. Also, GZB mRNA was negatively correlated with HDL-C and QUICKI index ( $r=-0.360$ and -0.427 at $P<0.01$ and 0.001 , respectively).

Table (2): Simple correlations of blood GZB mRNA levels with other metabolic parameters:

\begin{tabular}{|c|c|c|}
\hline \multirow{2}{*}{ Parameters } & \multicolumn{2}{|c|}{ Blood GZB mRNA } \\
\hline & $r$ & 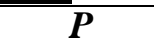 \\
\hline Triglycerides & 0.342 & 0.003 \\
\hline Total cholesterol & 0.426 & $<0.0001$ \\
\hline HDL-C & -0.360 & 0.002 \\
\hline LDL-C & 0.515 & $<0.0001$ \\
\hline TC/HDL-C & 0.475 & $<0.0001$ \\
\hline LDL-C/HDL-C & 0.463 & $<0.0001$ \\
\hline FBG & 0.564 & $<0.0001$ \\
\hline $\mathbf{H b A}_{1 \mathrm{c}} \%$ & 0.496 & $<0.0001$ \\
\hline HOMA-IR & 0.447 & $<0.0001$ \\
\hline QUICKI & -0.427 & $<0.0001$ \\
\hline hsCRP & 0.479 & $<0.0001$ \\
\hline WBCs count & 0.265 & 0.024 \\
\hline Neutrophils count & 0.305 & 0.009 \\
\hline
\end{tabular}

GZB, granzyme B; TC, total cholesterol; HDL-C, high density lipoprotein cholesterol; LDL-C; low density lipoprotein cholesterol; FBG, fasting blood glucose; GHbA1c, glycosylated hemoglobin; QUICKI, Quantitative insulin sensitivity check index; HOMA-IR, homeostasis model assessment of insulin resistance; hsCRP, high sensitivity C-reactive protein; WBCs, white blood cells 


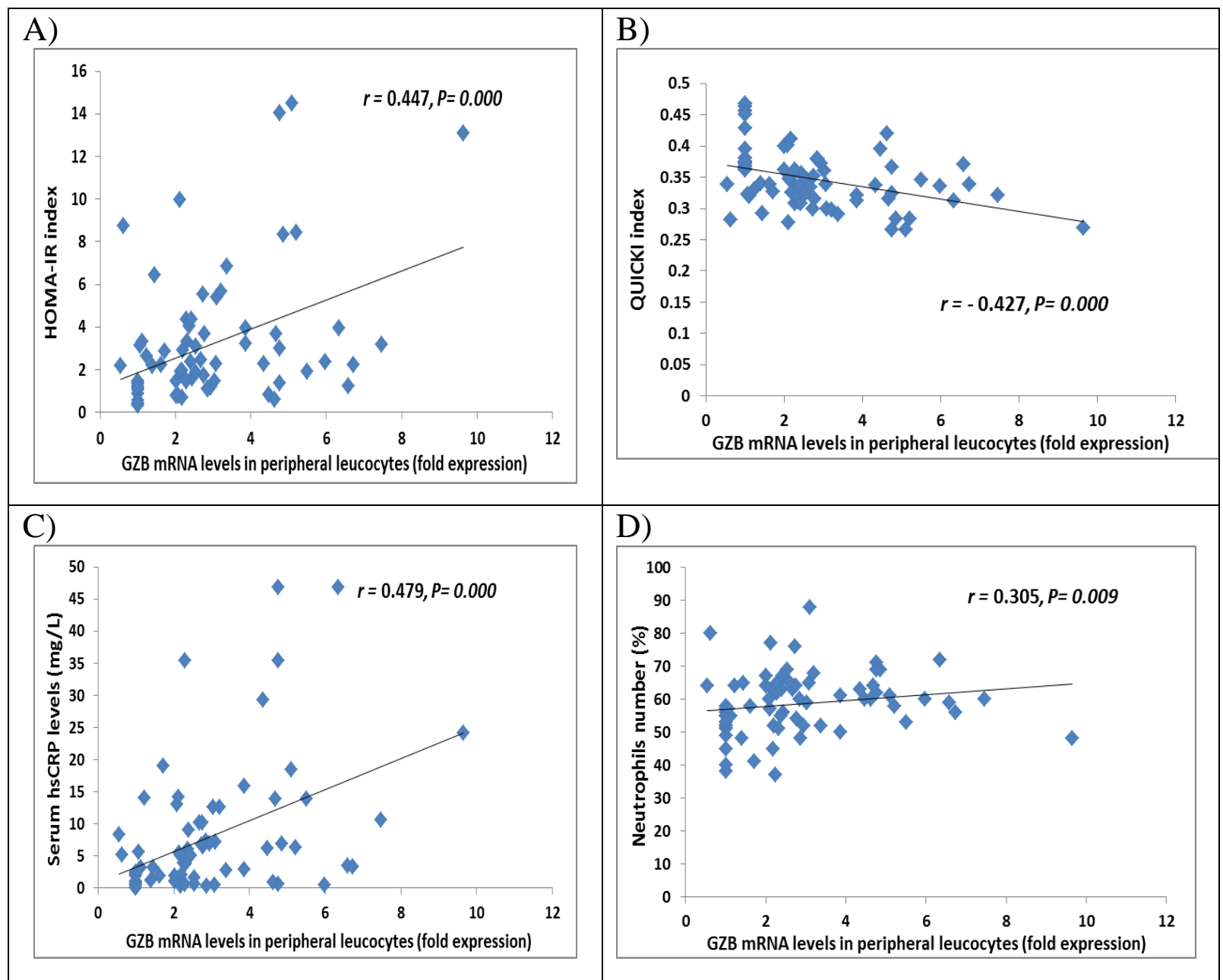

Figure (2): Correlation of GZB mRNA levels with different parameters (A) Correlation with HOMA-IR index (B) correlation with QUICKI index (C) Correlation with serum hsCRP levels (D) Correlation with neutrophils number.

\subsection{Multiple stepwise linear regression analysis for GZB mRNA as a dependent variable:}

We conducted simple linear regression, and then multiple stepwise linear regression analysis (Table 3) to identify predicting factors significantly associated with GZB gene expression levels. We set GZB mRNA levels as a dependent variable and age, BMI, current smoking, hypertension, DM, hypercholesterolemia, HOMA-IR, hsCRP and patient history of previous AMI as independent variables. Simple regression analysis revealed that hypertension, smoking, DM, hypercholesterolemia, HOMA-IR and hsCRP are positively predicting GZB mRNA levels. While multiple stepwise linear regression analysis demonstrated that DM and current smoking are predictors for GZB mRNA levels $(\beta=0.446$ and .258 at $P=0.000$ and 0.017, respectively). 
Table (3): Univariate and multiple stepwise linear regression analysis using GZB mRNA as dependent variables:

\begin{tabular}{|c|c|c|c|c|}
\hline \multirow{3}{*}{ Parameters } & \multicolumn{4}{|c|}{ GZB mRNA $^{\text {II }}$} \\
\hline & \multicolumn{2}{|c|}{ Simple univariate } & \multicolumn{2}{|c|}{$\underline{\text { Multiple stepwise }}$} \\
\hline & $\boldsymbol{\beta}$ & $\boldsymbol{P}$ & $\boldsymbol{\beta}$ & $P$ \\
\hline Age & 0.162 & 0.171 & ..... & ..... \\
\hline Body mass index & 0.167 & 0.159 & $\cdots \cdots$ & $\cdots \cdots$ \\
\hline Current smoking & 0.375 & 0.001 & 0.258 & 0.017 \\
\hline Hypertension & 0.384 & 0.001 & $\cdots \cdots$ & $\cdots \cdots$ \\
\hline Diabetes mellitus & 0.532 & 0.000 & 0.446 & 0.000 \\
\hline Hypercholesterolemia & 0.294 & 0.011 & $\cdots \cdots$ & $\cdots \cdots$ \\
\hline HOMA-IR $^{\text {II }}$ & 0.418 & 0.000 & $\ldots \ldots$ & $\ldots \ldots$ \\
\hline hsCRP $^{\|}$ & 0.348 & 0.004 & $\cdots \cdots$ & 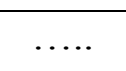 \\
\hline History of previous AMI & 0.250 & 0.034 & $\ldots \ldots$ & $\ldots$ \\
\hline
\end{tabular}

GZB, granzyme B; HOMA-IR, homeostasis model assessment of insulin resistance; hsCRP, high sensitivity C-reactive protein; AMI, acute myocardial infarction

II Log-transformed before analysis; $\mathrm{R}^{2}$ for stepwise regression model was $30.4 \%$

\section{DISCUSSION:}

Atherosclerosis is an inflammatory disease characterized by accumulation of lipids and many cells as SMCs, macrophages and T lymphocytes as well as extracellular matrix proteins (Libby, et al., 2009; Libby, et al., 2002). It is widely accepted that inflammation and insulin resistance are important players in atherosclerosis and type 2 DM (Libby, et al., 2009; Donath and Shoelson, 2011). Because of high mortality rate of CVD, identifying new pathways implicated in inflammation and insulin resistance is great for understanding this disease and provides hope for the development of novel therapeutic strategies aiming to reduce atherosclerosis-related mortality. Our interest in GZB is based on several points.

GZB is a serine protease produced by CTLs and macrophages. Both are central cells contributing to development and complications of human atherosclerotic plaques (Kyaw, et al., 2013; Choy, et al., 2003). Besides well recognized apoptotic role of GZB via perforindependent pathways, its extracellular role now received increased interest. Recent work by our co-workers has demonstrated elevated circulating levels of GZB in acute coronary syndrome (El-Mesallamy, et al., 2013), obesity and type 2 DM (El-Mesallamy, et al., 2013), suggesting important role of this protease in these inflammatory conditions. However, studies revealed increased expression of GZB in lipid rich areas of atherosclerotic plaques (Kim, et al., 2007; Choy, et al., 2003), the related mechanisms involved in atherosclerosis needs further investigation. Accordingly, our study evaluated the changes in gene expression of GZB in atherosclerotic patients with and without type $2 \mathrm{DM}$. We also focused on investigating its association with other metabolic parameters.

The current study demonstrated increased expression of GZB mRNA in peripheral blood of CAD patients with or without DM in comparison to control group. This finding comes in 
accordance with studies revealed increased circulating levels of GZB after AMI (Kondo, et al., 2009), stable and unstable angina pectoris (Tsuru, et al., 2008) as well as angina complicated with chronic kidney disease (Ikemoto, et al., 2009). Most of studies focused on GZB-mediated apoptosis and their contribution to atherosclerosis pathogenesis. While in our study, we studied GZB contribution to inflammation and other metabolic disturbances associated with atherogenesis. Correlation analysis showed that GZB mRNA levels were positively correlated with triglycerides, TC and LDL-C and negatively correlated with HDL-C, indicating its relation to lipid disorders involved in atherosclerosis development and progression.

Indeed, GZB mRNA is significantly associated with hsCRP, an important marker of chronic low-grade inflammation. Evidence from experimental and clinical studies has been accumulating that CRP is not just a sensitive markers of systemic inflammation but also an amplifier of it. It is widely accepted that hsCRP is an independent risk for CVD and could participate directly in the pathogenesis of atherosclerosis through a variety of mechanisms (Koenig and Khuseyinova, 2007; Yeh, et al., 2001). A reasonable explanation for correlation between GZB and hsCRP could be extracellular role of GZB in proteolysis of extracellular matrix proteins such as vitronectin, fibrillin and fibronectin and subsequent induction of macrophages to secrete proinflammatory cytokines (Buzza, et al., 2005; Chamberlain and Granville, 2007). Moreover, GZB may influence inflammation though direct activation of other cytokines as interleukin (IL)-18 and IL-1 $\beta$ by proteolytic cleavage of their inactive precursors at the same residue cleaved by caspase-1 (Omoto, et al., 2010). Furthermore, contribution of GZB to inflammation is supported by its positive correlation to WBCs count and neutrophils count. Both are well established markers of systemic inflammation and important players in atherogenesis (Ortega, et al., 2012; Soehnlein, 2012). High WBCs is not only a marker of activated immune system but also found to be associated with all stages of atherosclerosis independently of traditional risk factors (Ortega, et al., 2012).

With regards to insulin resistance, we demonstrated that GZB mRNA levels were positively correlated with $\mathrm{FBG}, \mathrm{HbA}_{1 \mathrm{c}} \%$ and $\mathrm{HOMA}-\mathrm{IR}$ as well as negatively associated with QUICKI index. Previously hyperglycemia was claimed to cause activation of CTLs (Stentz FB and Kitabchi, 2003) that could eventually lead to an increased release of GZB. Additionally, a recent study in our lab has shown that plasma GZB levels were elevated in patients with type 2 DM as compared to non-diabetic subjects and positively correlated with circulating insulin receptor $\alpha$-subunit levels (El Mesallamy, et al., 2013). The latter finding might support the new hypothesis of insulin resistance which based on cleavage of insulin receptor by proteases as serine proteases and matrix metalloproteinases (DeLano, et al., 2010). Association between GZB and insulin resistance could be also attributed to GZB-dependent induction of potential proinflammatory cytokines as IL-1 $\alpha$ and IL-18 (Omoto, et al., 2010; Afonina, et al., 2011). It is worse mentioning that association between GZB mRNA and WBCs count might support the possible role of GZB in insulin resistance as high WBCs was found to be a predictor for worsening in insulin sensitivity even in absence of adiposity (Vozarova, et al., 2002).

Moreover, multiple regression analysis demonstrated that DM is significantly associated with GZB mRNA levels. This comes in accordance with a study of Ikemoto and coworkers who found the contributory role of DM to plasma GZB levels in chronic renal failure patients (Ikemoto, et al., 2009). This could be attributed to increased cellular protein kinase $\mathrm{C}$ activity in diabetic patients and subsequent upregulation of GZB expression (Tsuru, et al., 2008). This is supported by elevation of GZB mRNA levels observed in CAD/diabetic patients as compared to 
non-diabetics. Therefore, GZB might be a candidate molecule involved in atherosclerosis with and without DM.

In conclusion, we demonstrated significant increase in GZB gene expression from circulating leucocytes in atherosclerotic patients with and without type 2 DM. Moreover, GZB gene is significantly associated with inflammation and insulin resistance, hallmarks of atherosclerosis. Therefore, we propose that the modulation of GZB signaling may attenuate atherosclerosis progression and reduce its complications associated with type 2 DM.

\section{Conflict of Interests}

The authors declare that there is no conflict of interests.

\section{ACKNOWLEDGEMENTS}

We want to express our deep appreciation to Military Central Laboratories, Cairo, Egypt for kindly allowing use of automated analyzers and thermal cyclers.

\section{REFERENCES:}

Afonina IS, Tynan GA, Logue SE, Cullen SP, Bots M, Lüthi A, Reeves E, McElvaney N, Medema JP, Lavelle EC and Martin SJ, (2011): Granzyme B-dependent proteolysis acts as a switch to enhance the proinflammatory activity of IL-1б. Mol cell; 44(2): 265-278.

Boivin WA, Cooper DM, Hiebert PR and Granville DJ, (2009): Intracellular versus extracellular granzyme B in immunity and disease: challenging the dogma. Lab Invest; 89(11): 1195-1120.

Buzza MS, Zamurs L, Sun J, Bird CH, Smith AI, Trapani JA, Froelich CJ, Nice EC and Bird PI, (2005): Extracellular matrix remodeling by human granzyme B via cleavage of vitronectin, fibronectin, and laminin. J Biol Chem; 280(25): 23549-23558.

Chamberlain CM and Granville DJ, (2007): The role of Granzyme B in atheromatous diseases. Can J Physiol Pharmacol; 85(1): 89-95.

Choy JC, McDonald PC, Suarez AC, Hung VH, Wilson JE, McManus BM and Granville DJ, (2003): Granzyme B in atherosclerosis and transplant vascular disease: association with cell death and atherosclerotic disease severity. Mod Pathol; 16(5): 460-470.

DeLano FA, Zhang $H$, Tran EE, Zhang $C$ and Schmid-Schönbein GW, (2010): New hypothesis for insulin resistance in hypertension due to receptor cleavage. Expert Rev Endocrinol Metab; 5(1): 149-158.

Donath MY and Shoelson SE, (2011): Type 2 diabetes as an inflammatory disease. Nat Rev Immunol; 11(2): 98-107.

El Mesallamy HO, Hamdy NM, Mostafa DM and Amin AI, (2013): The serine protease granzyme $\mathrm{B}$ as an inflammatory marker, in relation to the insulin receptor cleavage in human obesity and type 2 diabetes mellitus. J Interferon Cytokine Res; 34(3): 179-186. 
El-Mesallamy HO, Hamdy NM, El-Etriby AK and Wasfey EF, (2013): Plasma granzyme B in ST elevation myocardial infarction versus non-ST elevation acute coronary syndrome: comparisons with IL-18 and fractalkine. Mediators Inflamm; doi: 10.1155/2013/343268:

Ewen CL, Kane KP and Bleackley RC, (2012): A quarter century of granzymes. Cell Death Differ (2012); 19(1): 28-35.

Gregg EW, Gu Q, Cheng YJ, Narayan KM and Cowie CC, (2007): Mortality trends in men and women with diabetes, 1971 to 2000. Ann Intern Med; 147(3): 149-155.

Grundy S, Benjamin I, Burke G, Chait A, Eckel RH, Howard BV, Mitch W, Smith SC Jr and Sowers JR, (1999): Diabetes and cardiovascular disease: a statement for healthcare professionals from the American Heart Association. Circulation; 100(10): 1134-46.

Ikemoto T, Hojo Y, Kondo H, Takahashi N, Hirose M, Nishimura Y, Katsuki T and Shimada $K$, (2009): Plasma granzyme B as a predicting factor of coronary artery diseaseclinical significance in patients with chronic renal failure. J Cardiol; 54(3): 409415.

Katz A, Nambi SS, Mather K, Baron AD, Follmann DA, Sullivan G and Quon MJ, (2000): Quantitative insulin sensitivity check index: a simple, accurate method for assessing insulin sensitivity in humans. J Clin Endocrinol Metab; 85(7): 24022410.

Kim WJ, Kim H, Suk K and Lee WH, (2007): Macrophages express granzyme B in the lesion areas of atherosclerosis and rheumatoid arthritis. Immunol Lett; 111(1): 57-65.

Koenig $W$ and Khuseyinova $N$, (2007): Biomarkers of atherosclerotic plaque instability and rupture. Arterioscler Thromb Vasc Biol; 27: 15-26.

Kondo H, Hojo Y, Tsuru R, Nishimura Y, Shimizu H, Takahashi N, Hirose M, Ikemoto T, Ohya K-i, Katsuki T, Yashiro T and Shimada K, (2009): Elevation of plasma granzyme B levels after acute myocardial infarction. Circ J; 73(3): 503-507.

Kyaw T, Winship A, Tay C, Kanellakis P, Hosseini H, Cao A, Li P, Tipping P, Bobik A and Toh BH, (2013): Cytotoxic and proinflammatory CD8+ T lymphocytes promote development of vulnerable atherosclerotic plaques in apoE-deficient mice. Circulation; 127(9): 1028-1039.

Libby P, Ridker PM and Hasson GK, (2009): Inflammation in atherosclerosis: from pathophysiology to practice. J Am Coll Cardiol; 54(23): 2129-2138.

Libby P, Ridker PM and Maseri A, (2002): Inflammation and atherosclerosis. Circulation; 105: 1135-1143.

Mallat Z, Taleb S, Ait-Oufella $\mathrm{H}$ and Tedgui A, (2009): The role of adaptive T cell immunity in atherosclerosis. J Lipid Res; 50: S364-S369.

Matthews DR, Hosker JP, Rudenski AS, Naylor BA, Treacher DF and Turner RC, (1985): Homeostasis model assessment: insulin resistance and beta-cell function from fasting plasma glucose and insulin concentrations in man. Diabetologia; 28(7): 412-419. 
Omoto Y, Yamanaka K, Tokime K, Kitano S, Kakeda M, Akeda T, Kurokawa I, Gabazza EC, Tsutsui H, Katayama N, Yamanishi K, Nakanishi K and Mizutani H, (2010): Granzyme B is a novel interleukin-18 converting enzyme. J Dermatol Sci (2010); 59(2): 129-135.

Ortega E, Gilabert R, Nunez I, Cofan M, Sala-Vila A, de Groot E and Ros E, (2012): White blood cell count is associated with carotid and femoral atherosclerosis. Atherosclerosis; 221(1): 275-81.

Ovchinnikova O, Robertson AK, Wågsäter D, Folco EJ, Hyry M, Myllyharju J, Eriksson P, Libby $P$ and Hansson GK, (2009): T-cell activation leads to reduced collagen maturation in atherosclerotic plaques of Apoe ${ }^{-/-}$mice. Am J Pathol; 174(2): 693700 .

Pardo J, Wallich R, Ebnet K, Iden S, Zentgraf H, Martin P, Ekiciler A, Prins A, Müllbacher A, Huber M and Simon MM, (2007): Granzyme B is expressed in mouse mast cells in vivo and in vitro and causes delayed cell death independent of perforin. Cell Death Differ; 14(10): 1768-1779.

Prakash MD, Bird CH and Bird PI, (2008): Active and zymogen forms of granzyme B are constitutively released from cytotoxic lymphocytes in the absence of target cell engagement. Immunol Cell Biol; 87(3): 249-254.

Preis SR, Hwang SJ, Coady S, Pencina MJ, D'Agostino RB Sr, Savage PJ, Levy D and Fox $C S$, (2009): Trends in all-cause and cardiovascular disease mortality among women and men with and without diabetes mellitus in the Framingham Heart Study, 1950 to 2005. Circulation; 119(13): 1728-1735.

Schaub N, Reichlin T, Meune C, Twerenbold R, Haaf P, Hochholzer W, Niederhauser N, Bosshard P, Stelzig C, Freese M, Reiter M, Gea J, Buser A, Mebazaa A, Osswald $S$ and Mueller $C$, (2012) : Markers of plaque instability in the early diagnosis and risk stratification of acute myocardial infarction. Clin Chem.; 58(1): 246-256.

Shoelson SE, Lee J and Goldfine AB, (2006): Inflammation and insulin resistance. J Clin Invest; 116(7): 1793-1801.

Soehnlein O, (2012): Multiple Roles for Neutrophils in Atherosclerosis. Circ Res; 110(6): 875888.

Stentz FB and Kitabchi AE, (2003): Activated T lymphocytes in type 2 diabetes: implications from in vitro studies. Curr Drug Targets; 4(6): 493-503.

Tsuru R, Kondo H, Hojo Y, Gama M, Mizuno O, Katsuki T, Shimada K, Kikuchi M and Yashiro T, (2008): Increased granzyme B production from peripheral blood mononuclear cells in patients with acute coronary syndrome. Heart; 94(3): 305310 .

Vozarova B, Weyer C, Lindsay R, Pratley RE, Bogardus $C$ and Tataranni PA, (2002): High white blood cell count is associated with a worsening of insulin sensitivity and predicts the development of type 2 diabetes. Diabetes; 51(2): 455-461.

Yeh ET, Anderson HV, Pasceri V and Wilkerson JT, (2001): C-reactive protein linking inflammation to cardiovascular complications. Circulation; 104: 974-975. 


\section{تأثير التعبير الجيني للجرانزيوم ب على الالتهاب ومقاومة الانسولين في تصلب الثرايين}

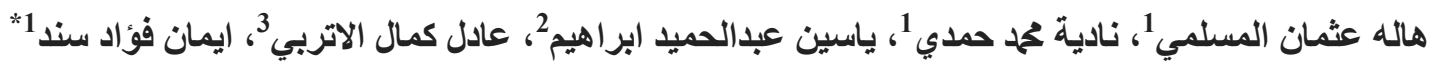

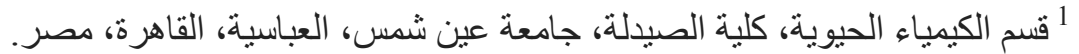

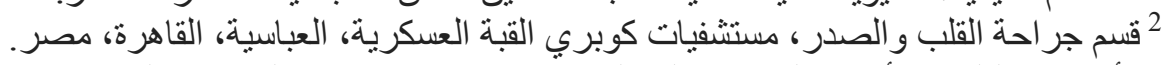

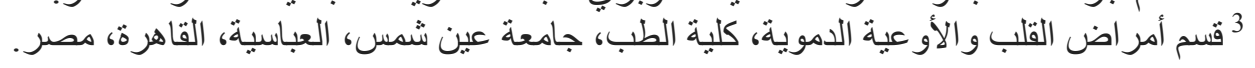

الخلفية / الهوف: تصلب الثر ايين هو مرض التهابي يتميز بتجمع العديد من الخلايا المناعية. وتعتبر الخلايا تي الليمفاوية

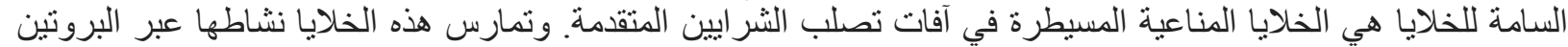

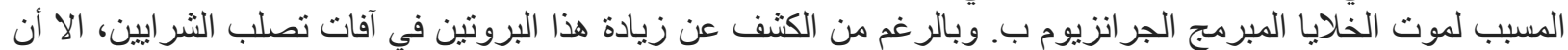

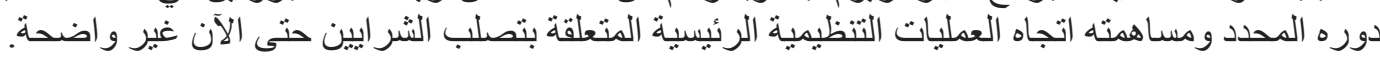

طرق البحث: تم قياس التعبير الجيني للجرانزيوم ب في كريات الدم البيضاء في عدد 15 من المتطوعين الأصحاء يمثلون

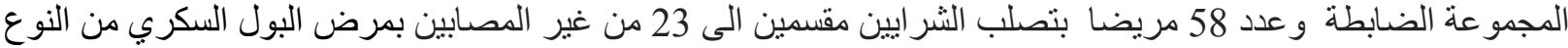

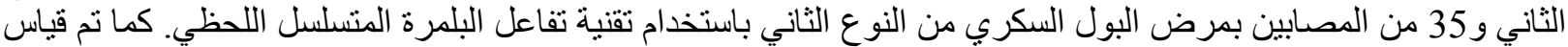

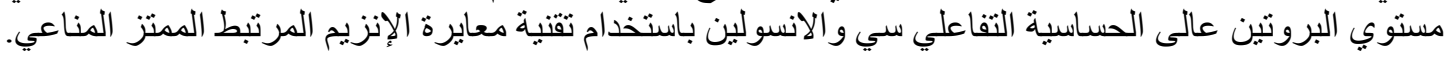

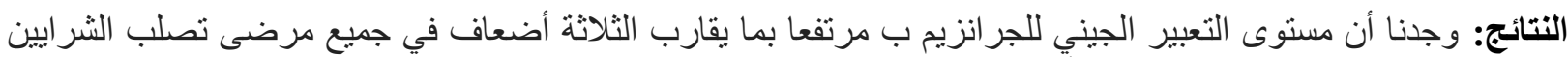

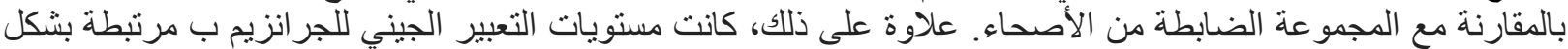

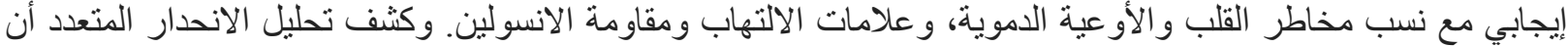

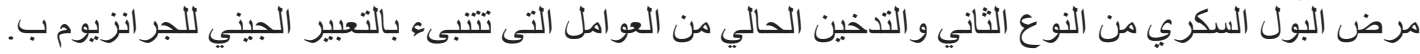

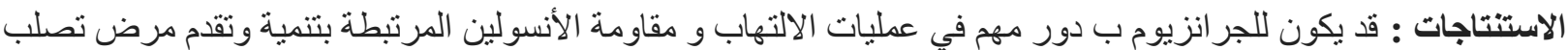
الثر ايين . الكلمات الادالة: الجر انزيوم ب، الالتهاب، مقاومة الأنسولين، وتصلب الثر ايين 